\title{
Molecular analysis of pathogenic Escherichia coli isolated from cow meat in Yogyakarta, Indonesia using 16S rRNA gene
}

\author{
ALVITA INDRASWARI ${ }^{1}$, I WAYAN SUARDANA ${ }^{2}$, ARIS HARYANTO ${ }^{3}$, DYAH AYU WIDIASIH ${ }^{4, \bullet}$ \\ ${ }^{1}$ Doctoral Program of Veterinary Science, Faculty of Veterinary Medicine, Universitas Gadjah Mada. Jl. Fauna No. 2 Karangmalang, Sleman 55281, \\ Yogyakarta, Indonesia \\ ${ }^{2}$ Department of Veterinary Public Health, Faculty of Veterinary Medicine, Universitas Udayana. J1. P.B. Sudirman, Denpasar 80232, Bali, Indonesia \\ ${ }^{3}$ Department of Biochemistry, Faculty of Veterinary Medicine, Universitas Gadjah Mada. Jl. Fauna No. 2, Karangmalang, Sleman 55281, Yogyakarta, \\ Indonesia \\ ${ }^{4}$ Department of Veterinary Public Health, Faculty of Veterinary Medicine, Universitas Gadjah Mada, Jl. Fauna No. 2 Karangmalang, Sleman 55281, \\ Yogyakarta, Indonesia. Tel.: +62-274-560866, Fax.: +62-274-560866, `email: dyahaw@ugm.ac.id
}

Manuscript received: 3 August 2021. Revision accepted: 28 September 2021.

\begin{abstract}
Indraswari A, Suardana IW, Haryanto A, Widiasih DA. 2021. Molecular analysis of pathogenic Escherichia coli isolated from cow meat in Yogyakarta, Indonesia using 16S rRNA gene. Biodiversitas 22: 4566-4573. Meat has been recognized as a major source of foodborne disease and a public health problem. The characteristics of meat become an ideal growth medium for various microorganisms if not handled properly. Pathogenic Escherichia coli is one of the foodborne disease agents that causes diarrhea. Identification of pathogenic E. coli isolated from cow meat needs to be done. This research aims to study nucleotide sequence of 16S rRNA gene of pathogenic E. coli isolated from cow meat in Yogyakarta, Indonesia using Polymerase Chain Reaction (PCR). These fifteen isolates have been detected for eae target gene, then amplification of the 16S rRNA gene was carried out using primers $27 \mathrm{~F}$ and $1492 \mathrm{R}$. Phylogenetic tree reconstruction was performed on the fifteen isolates of pathogenic $E$. coli to figure out the relationship to reference strains available at the GenBank. Results show that nucleotide sequence among the fifteen isolates from different traditional markets in Yogyakarta, Indonesia and reference strains are very similar. The fifteen isolates have small genetic distance to the reference strains, and these fifteen isolates are also in the same clade with reference strains. This research shows that the fifteen isolates under investigation are closely related to the reference strains, which is Shiga-toxin producing E. coli (STEC). People should pay more attention in processing food stock, especially cow meat. Further research may focus on determining the strain of those fifteen isolates.
\end{abstract}

Keywords: 16S rRNA, cow meat, DNA sequencing, pathogenic E. coli, phylogenetic

\section{INTRODUCTION}

Some strains of pathogenic Escherichia coli may cause diarrhea or other extraintestinal diseases among healthy individuals and those with immunocompromised (Gomes et al. 2016; Antaki-zukoski et al. 2018; Habets et al. 2020; Vidal et al. 2020). There are six pathotypes related to diarrhea and commonly referred to as diarrheagenic E. coli (DEC) (Nataro and Kaper 1998; Jafari et al. 2012; CDC 2014; Gomes et al. 2016; CFSPH 2016). One of the pathotypes is Shiga-toxin producing E. coli (STEC), STEC is also known as Verocytotoxin-producing E. coli (VTEC) or enterohemorrhagic E. coli (EHEC). This pathotype is one of the most commonly recognized associated with foodborne disease (CDC 2014). Shiga-toxin producing $E$. coli has the virulence factors of Shiga-toxin (Stx) 1 and 2, encoded by the Stx1 and Stx 2 genes, respectively. In addition, most STECs have an adhesin protein called intimin which is encoded by the eae gene and allows the attachment of bacteria to the intestinal epithelium. The attachment induces histopathological lesions defined as attaching and effacing (A/E). This lesion is regulated by a large pathogenicity island called the locus of enterocyte effacement (LEE) (Donnenberg et al. 1993); Nataro and Kaper 1998; Blanco et al. 2004; Croxen and Finlay 2010).
It has been found the eae gene in both the feces of cows suffering from diarrhea or not (Yousif and Hussein 2015). There is a strong association with the discovery of the eae gene and the ability of STEC to cause severe disease in humans, particularly hemolytic uremic syndrome (HUS) (Oswald et al. 2000).

In Indonesia, diarrheagenic $E$. coli has been found in cow meat obtained from qurban animals (Ningrum et al. 2016) and slaughterhouses (Rananda et al. 2016; Suardana et al. 2007). In the meat of slaughtered cattle obtained from Jakarta, 5.3\% of non-O157 Shiga-toxin (STEC) producing E. coli were found (Ningrum et al. 2016). It was found that $70 \%$ of cow meat samples obtained from the Lubuk Buaya abattoir, Padang, were found to be contaminated with $E$. coli $\mathrm{O} 157: \mathrm{H} 7$ with the number of colonies that had exceeded the maximum permissible contamination limit (Rananda et al. 2016). According to Suardana et al. (2007), $5.62 \%$ E. coli $\mathrm{O} 157: \mathrm{H} 7$ in cow meat obtained from slaughterhouses and traditional markets in Badung Regency, Bali. The discovery of diarrheagenic E. coli in cow meat indicates a critical role as a reservoir for strains that transmit disease to humans. Food produce from animals such as cow may be contaminated with DEC at the slaughterhouse, processing facility, or the consumer's kitchen. DEC infection may also come from consumption 
of raw or rare meat, unpasteurized milk, and fruits and vegetables contaminated with feces. Bacterial transmission may also occur from one human to another (WHO 2018).

DEC strain is one of the first pathogens to be observed using today's advanced molecular diagnostic methods. These methods are the most popular and reliable in differentiating DEC strain from those of non-pathogenic bacteria. Moreover, the phylogeny and taxonomy of bacteria can also be studied using 16S rRNA gene sequence as genetic markers (Fujioka et al. 2009; Amarantini et al. 2011; Botkin et al. 2012; Fialho et al. 2013; Suardana 2014). The gene sequence of $16 \mathrm{~S}$ rRNA is used because 16S rRNA gene is found in almost all bacteria, 16S rRNA gene does not change its function over time, and 16S rRNA gene (1500 bp) is large enough for information purposes. One of the most interesting potentials of $16 \mathrm{~S}$ rRNA gene is its ability to provide genus and species identification for isolates that do not match standard biochemistry profiles, for strains that only result in low likelihood or acceptable identification according to commercial systems, or for taxa that are rarely associated with communicable diseases in human (Patel 2001; Pangastuti 2006; Janda and Abbott 2007).

Characteristics of molecular targets from these methods allow the study of bacterial phylogenetic, both for bacteria detection or identification in clinical laboratories (Rahmani et al. 2006; Amarantini et al. 2011; Rinanda 2011; Suardana 2014; Ghazali and Rashid 2019). This research aims to study nucleotide sequence of $16 \mathrm{~S}$ rRNA gene of pathogenic E. coli isolated from cow meat in Yogyakarta using Polymerase Chain Reaction (PCR). Results from this research can be used to understand the diversity of pathogenic E. coli based on nucleotide sequence and relationships among isolates that are isolated from cow meat available in traditional markets around Yogyakarta Special Region. In turn, it may increase people's awareness of E. coli.

\section{MATERIALS AND METHODS}

\section{Bacteria isolates}

This research employed $15 \mathrm{E}$. coli isolates coded as samples D1, KR3-2, KR1-3, N2, D1-2, D2-2, D4-2, D1-3, D4-3, N1-2, N2-2, N2-3, L2-2, L1-2, and N1-3. The bacterial isolates were obtained from previous studies which were isolated from 48 samples of meat in several traditional markets in Yogyakarta, Indonesia. There were 12 meat samples from the Demangan market (D) and 6 isolates, 26 meat samples from the Kranggan market (KR) and 2 isolates, 6 meat samples from the Ngasem market (N) and 5 isolates, and 4 meat samples from the Lempuyangan market (L) and 2 isolates were found. These fifteen isolates have been detected for eae target gene and have been identified as pathogenic $E$. coli with such gene present (Indraswari et al. 2021).

\section{Cultivation of bacteria isolates}

These fifteen isolates were taken from isolate stock kept in a freezer at $-20{ }^{\circ} \mathrm{C}$. These were then grown in Brain
Heart Infusion Broth (BHIB) media and incubated for $24 \mathrm{~h}$ at $37^{\circ} \mathrm{C}$. Bacterial growth was evident with increasing turbidity of BHIB media.

\section{DNA extraction}

The E. coli isolates grown in BHIB then underwent DNA extraction using Presto ${ }^{\mathrm{TM}}$ Mini gDNA Bacteria Kit (Geneaid GBB300) according to the procedure of choice with little modification as in Indraswari et al. (2021).

\section{Amplification of 16S rRNA gene using PCR and DNA sequencing}

DNA from extraction was used as DNA template for amplification using PCR master cycler personal. Component mixture for each reaction consisted of $4 \mu \mathrm{L}$ DNA template, each with forward and reverse primer taken from IDT ${ }^{\mathrm{TM}}$ of $2 \mu \mathrm{L}$, PCR mix from MyTaq ${ }^{\mathrm{TM}} \mathrm{HS}$ Red Mix (Cat. No.: BIO-25048) of $25 \mu \mathrm{L}$, and sterile $\mathrm{ddH}_{2} \mathrm{O}$ from UltraPure ${ }^{\mathrm{TM}} \mathrm{ddH}_{2} \mathrm{O}$ (Cat No.: 10977015) was also added that the total volume required for each reaction was $50 \mu \mathrm{L}$. The primers used were 27F: 5'AGAGTTTGATCCTGGCTCAG-3' and 1492R: 5'GGTTACCTTGTTACGACTT-3' (Suardana 2014). Amplification was performed at $95^{\circ} \mathrm{C}$ for $2 \mathrm{~min}$ (initial denaturation), and further 30 cycles at $95^{\circ} \mathrm{C}$ for $45 \mathrm{~s}$ (denaturation), at $50^{\circ} \mathrm{C}$ for $45 \mathrm{~s}$ (annealing), and at $72^{\circ} \mathrm{C}$ for $1 \mathrm{~min}$ (extension). Amplification program was ended at $72^{\circ} \mathrm{C}$ for $5 \mathrm{~min}$ (final extension). Around $5 \mu \mathrm{L}$ of amplification result was then analyzed using electrophoresis in $1.5 \%$ agarose gel colored with SYBR® Safe DNA gel stain in TBE $1 \times$ solution. This gel was visualized using a UV transilluminator and documented using a digital camera. Obtained PCR products were then sent to PT. Genetika Science, Indonesia for DNA sequencing. Sequencing was performed using two primers of $27 \mathrm{~F}$ and $1492 \mathrm{R}$.

\section{Analysis of 16S rRNA gene sequencing}

The length of 16S rRNA gene amplification product was $\sim 1500 \mathrm{bp}$ and data from this sequencing were further analyzed using Molecular Evolutionary Genetics Analysis (MEGA)-X software. Nucleotide sequences of $16 \mathrm{~S}$ rRNA gene from pathogenic E. coli available at the GenBank include E. coli Sakai (BA000007), E. coli O104:H4 (AFOB02000112), E. coli EDL 933 W (AE005174), E. coli SM-25(1) (KF768068), E. coli KL-48(2) (KF768069), E. coli O111:H- (GU237022), and E. coli O121:H19 (JASV01000004) which were used as reference and Shigella sonnei (FR870445) which was used as an outgroup. Sequence of $16 \mathrm{~S}$ rRNA gene was aligned using Clustal W program and was automatically compared using BLAST against bacteria sequence available at the GenBank (http://www.ncbi.nlm.nih.gov/). Analysis of genetic profile was determined by differences in nucleotide sequence of $16 \mathrm{~S}$ rRNA gene. Genetic distance was measured using the Kimura 2-parameter method. Afterward, a phylogenetic tree was constructed using neighbor joining algorithm method with $1000 \times$ replication bootstrap test and the Kimura 2-parameter method using MEGA program (Saitou and Nei 1987; Suardana et al. 2017; Kumar et al. 2018). 
Confirmation for species identification was also made based on the guidelines recommended by Janda and Abbott (2007).

\section{RESULTS AND DISCUSSION}

The fifteen $E$. coli isolates used in this research were isolated from cow meat sold in different traditional markets in Yogyakarta, Indonesia. They underwent detection for eae gene target and were identified as pathogenic E. coli as such gene was present (Indraswari et al. 2021). After bacteria isolate cultivation, DNA extraction was performed on them in order to obtain DNA template for amplification with PCR.

\section{Amplification of 16S rRNA gene}

Results of 16S rRNA gene amplification using primers $27 \mathrm{~F}$ and $1492 \mathrm{R}$ are depicted in Figure 1. A positive result was indicated by the appearance of a DNA band measuring $\sim 1500 \mathrm{bp}$. In all the studied isolates, DNA bands appeared at the appropriate size. Positive PCR results were sequenced to determine the base sequence of the 16S rRNA gene from each isolate.

\section{Analysis of 16S rRNA gene sequencing Alignment of $16 S$ rRNA gene}

The alignment of the 16S rRNA gene of the fifteen isolates against several reference strains available in Genbank is shown in Figure 2. Data from the alignment of the $16 \mathrm{~S}$ rRNA gene showing similarities or differences between the aligned nucleotide sequences. The nitrogen base number 39 of isolates D1, KR3-2, and N2 is different from E. coli Sakai, E. coli O104:H4, and Shigella sonnei with base A replaced by bases $\mathrm{C}$ and $\mathrm{T}$. Other than that, the nitrogen base number 24 from isolates D1, KR3-2, KR1-3, D2-2, D4-2, D1-3, D4-3, N1-2, N2-2, N2-3, L2-2, L1-2, and N1-3 only differs from E. coli Sakai with base C replaced by base $\mathrm{A}$. The fifteen isolates studied tended to show a close nucleotide sequence with isolates from the same species. The nucleotide sequences among the fifteen isolates under investigation are also closely related.

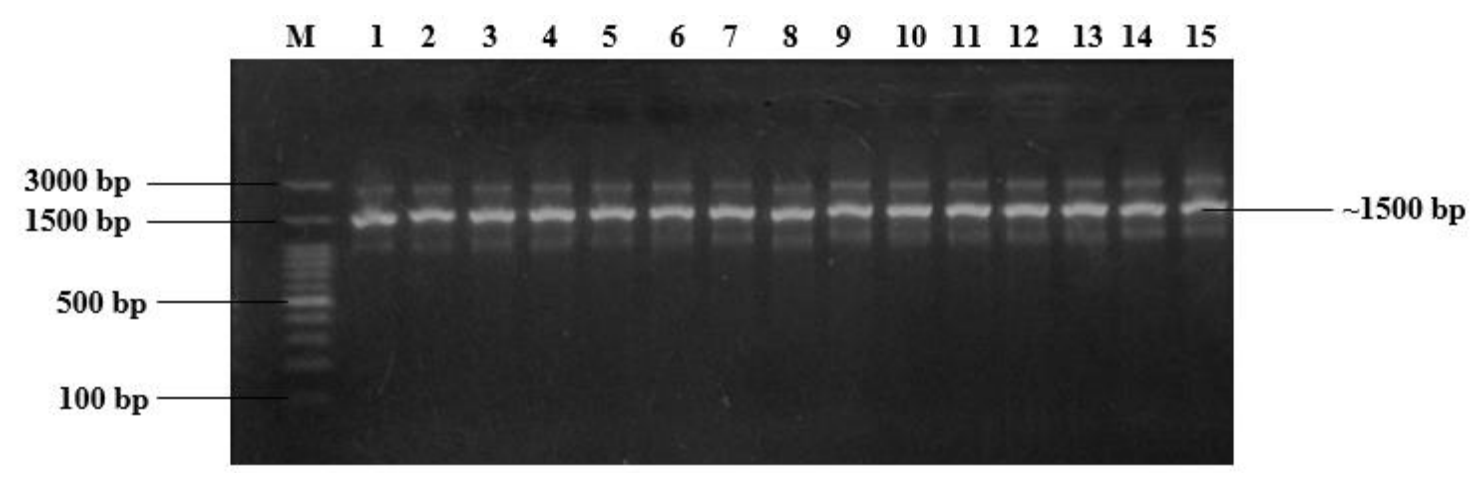

Figure 1. DNA band from 16S rRNA gene amplification in fifteen isolates of pathogenic E. coli. M: marker, 1: D1, 2: KR3-2, 3: KR13, 4: N2, 5: D1-2, 6: D2-2, 7: D4-2, 8: D1-3, 9: D4-3, 10: N1-2, 11: N2-2, 12: N2-3, 13: L2-2, 14: L1-2, and 15: N1-3
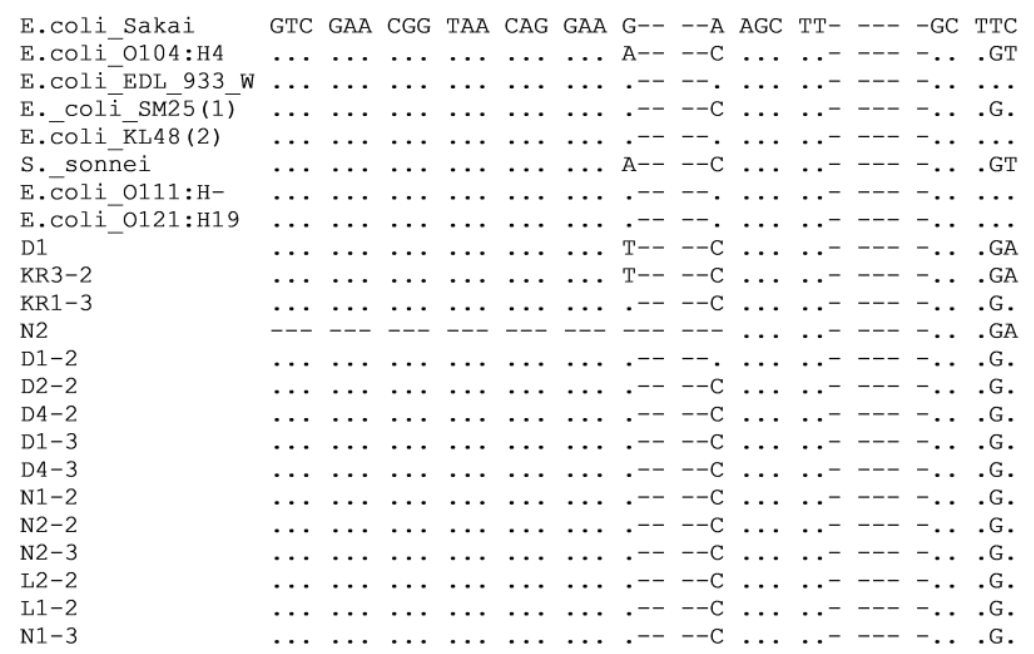

$\left[\begin{array}{l}39] \\ {\left[\begin{array}{l}39 \\ 39\end{array}\right]} \\ 39] \\ {\left[\begin{array}{l}39 \\ 39\end{array}\right]} \\ {\left[\begin{array}{l}39 \\ 39\end{array}\right]} \\ {\left[\begin{array}{l}39 \\ 39\end{array}\right]} \\ {\left[\begin{array}{l}39 \\ 39\end{array}\right]} \\ {\left[\begin{array}{l}39 \\ 39\end{array}\right]} \\ {\left[\begin{array}{l}39 \\ 39 \\ 39\end{array}\right]} \\ {\left[\begin{array}{l}39 \\ 39\end{array}\right]} \\ {\left[\begin{array}{l}39 \\ 39\end{array}\right]} \\ {\left[\begin{array}{l}39 \\ 39\end{array}\right]} \\ {\left[\begin{array}{l}39 \\ 3\end{array}\right]} \\ {\left[\begin{array}{l}39 \\ 39\end{array}\right]} \\ {\left[\begin{array}{l}39 \\ 3\end{array}\right]} \\ {\left[\begin{array}{l}39 \\ {[}\end{array}\right]}\end{array}\right]$

Figure 2. The nucleotide sequences of the $16 \mathrm{~S}$ rRNA gene from the fifteen isolates were compared with the nucleotide sequences available in GenBank. Data from the alignment results are not fully displayed 


\section{Genetic distance}

Results of genetic distance analysis from fifteen isolates under investigation against some strains of pathogenic $E$. coli and the outgroup of S. sonnei are given in Table 1. The fifteen isolates studied have different nucleotide sequence from 1 through 11 against reference strains available at the GenBank. Nucleotide analysis showed that the fifteen isolates studied were identical even though they had 1 to 11 nucleotide differences from the reference strain. For instance, between isolate D1 and E. coli Sakai only 3 nucleotides of 1000 being compared are found to be different. For isolate KR3-2, of 1000 nucleotide compared, only 4 are found to be different from those of E. coli SM25(1). For isolate N2, only 1 nucleotide is different from those of E. coli SM-25(1) and S. sonnei out of 1000 being compared.

The closest genetic distance between the fifteen isolates under investigation and reference strains can be summarized as follows: isolate N2, D1-2, and D2-2 show the smallest genetic distance to E. coli SM-25(1) strain. Other than that, isolate $\mathrm{N} 2$ also shows the smallest genetic distance to $S$. sonnei, and isolate D1-2 shows the smallest genetic distance to $E$. coli O121:H19 strain. The biggest genetic distance is between isolate D1 and E. coli
O121:H19, N2 and E. coli O111:H-, and L1-2 and E. coli O104:H4 and also E. coli O121:H19. Moreover, each of the fifteen isolates studied has a different nucleotide sequence from 1 through 10. The smallest genetic distance is between isolate D1 and L1-2 and also N1-3, KR1-3 and D1-3 and also N2-2, D1-2 and L2-2, D1-3 and N2-2, N2-2 and N1-3, N2-3 and N1-3, and L1-2 and N1-3. The biggest genetic distance is between isolate D1 and D1-2, KR1-3 and N2 and also D2-2, and D2-2 and N2-2.

\section{Phylogenetic tree}

Genetic distance measurements were then used to construct a phylogenetic tree of the fifteen isolates and reference strains available at the GenBank as depicted in Figure 3. The phylogenetic tree shows the existence of two clades, namely clade 1 and clade 2 . Clade 1 consists of the isolate D1-2, L2-2, D2-2, N2, N1-2, D4-2, and KR3-2 which is in the same clade with the reference strains of $E$. coli O104:H4, E. coli O121:H19, E. coli SM-25(1) and $E$. coli KL-48(2). Clade 2 consists of the isolate D4-3, N2-3, L1-2, N1-3, D1, KR1-3, D1-3, and N2-2 which is in the same clade with the reference strains of $E$. coli Sakai, $E$. coli $\mathrm{EDL} 933 \mathrm{~W}$, and E. coli $\mathrm{O} 111: \mathrm{H}-$.

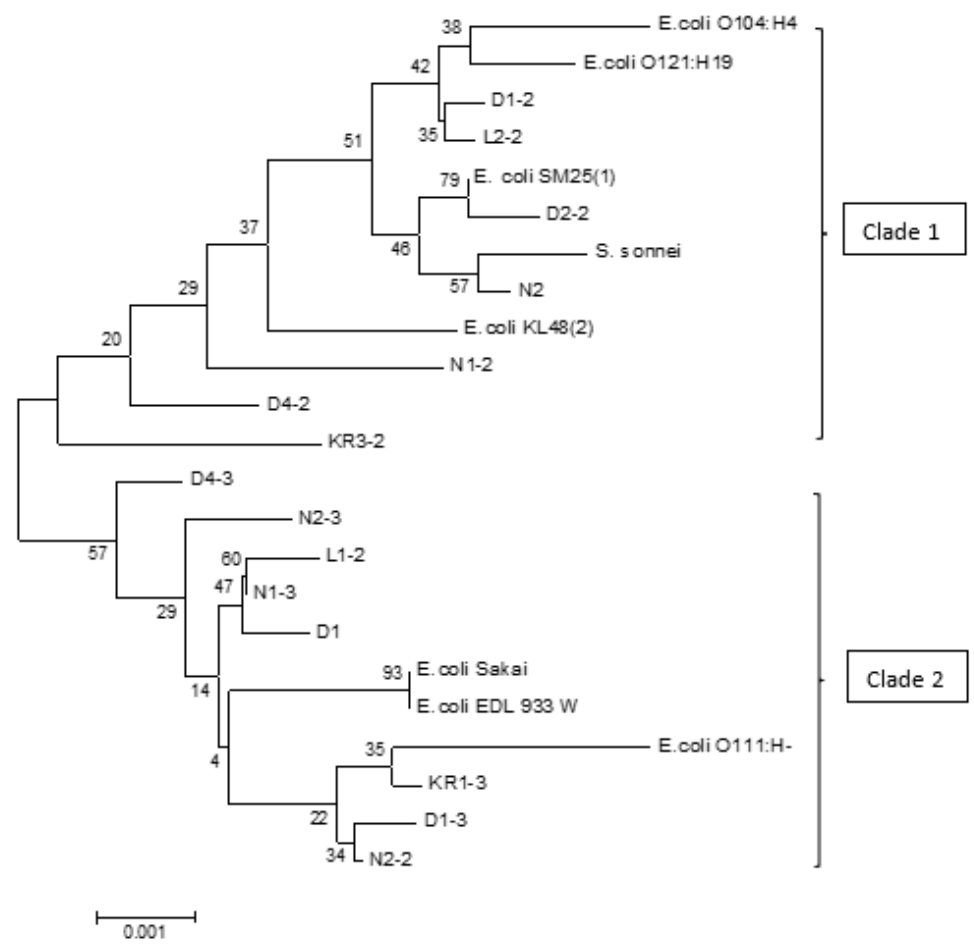

Figure 3. Phylogenetic tree among fifteen isolates and reference strains available on GenBank 
Table 1. The genetic distance among fifteen isolates with data from GenBank of the 16S rRNA genes

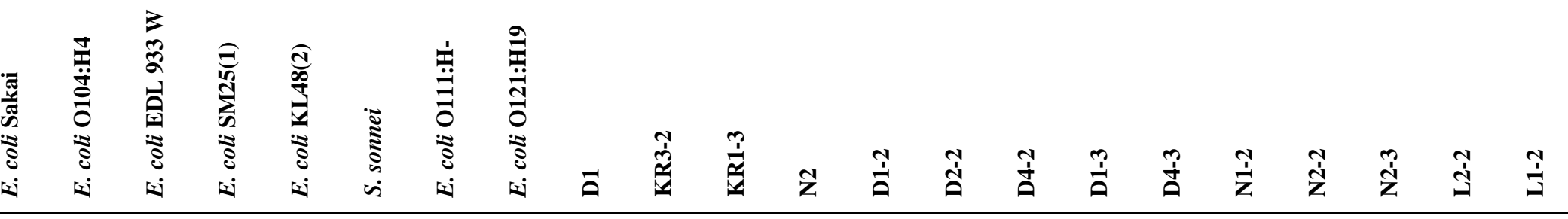

E. coli_Sakai

E. coli_O104:H4

E.coli_EDL_933_W

E. coli_SM25(1)

E. coli_KL48(2)

S._sonnei

0.013

$0.000 \quad 0.013$

$\begin{array}{lll}0.008 & 0.004 & 0.008\end{array}$

$\begin{array}{llll}0.007 & 0.007 & 0.007 & 0.003\end{array}$

E. coli $\mathrm{O} 111: \mathrm{H}-$

E. coli_O121:H19

D1

$\begin{array}{lllll}0.010 & 0.004 & 0.010 & 0.002 & 0.005\end{array}$

$\begin{array}{llllll}0.004 & 0.010 & 0.004 & 0.010 & 0.008 & 0.012\end{array}$

$\begin{array}{lllllll}0.010 & 0.003 & 0.010 & 0.003 & 0.004 & 0.005 & 0.007\end{array}$

$\begin{array}{lllllllll}0.003 & 0.010 & 0.003 & 0.008 & 0.008 & 0.008 & 0.006 & 0.011\end{array}$

$\begin{array}{llllllllll}0.007 & 0.007 & 0.007 & 0.004 & 0.004 & 0.004 & 0.010 & 0.007 & 0.004\end{array}$

$\begin{array}{lllllllllll}0.004 & 0.008 & 0.004 & 0.010 & 0.010 & 0.010 & 0.003 & 0.008 & 0.003 & 0.007\end{array}$

$\begin{array}{llllllllllll}0.010 & 0.004 & 0.010 & 0.001 & 0.004 & 0.001 & 0.011 & 0.004 & 0.007 & 0.003 & 0.010\end{array}$

$\begin{array}{llllllllllll}0.010 & 0.003 & 0.010 & 0.001 & 0.004 & 0.004 & 0.008 & 0.001 & 0.010 & 0.006 & 0.008 & 0.003\end{array}$

$\begin{array}{lllllllllllllll}0.009 & 0.005 & 0.009 & 0.001 & 0.004 & 0.003 & 0.010 & 0.004 & 0.009 & 0.005 & 0.010 & 0.002 & 0.002\end{array}$

$\begin{array}{llllllllllllll}0.007 & 0.006 & 0.007 & 0.006 & 0.006 & 0.008 & 0.005 & 0.004 & 0.007 & 0.006 & 0.004 & 0.007 & 0.004 & 0.007\end{array}$

$\begin{array}{lllllllllllllllll}0.004 & 0.008 & 0.004 & 0.008 & 0.008 & 0.009 & 0.004 & 0.008 & 0.003 & 0.006 & 0.001 & 0.008 & 0.007 & 0.009 & 0.004\end{array}$

$\begin{array}{llllllllllllllllll}0.003 & 0.010 & 0.003 & 0.005 & 0.005 & 0.007 & 0.006 & 0.008 & 0.003 & 0.004 & 0.004 & 0.007 & 0.007 & 0.006 & 0.005 & 0.004\end{array}$

$\begin{array}{llllllllllllllllll}0.009 & 0.007 & 0.009 & 0.005 & 0.005 & 0.007 & 0.007 & 0.005 & 0.009 & 0.007 & 0.007 & 0.007 & 0.004 & 0.006 & 0.004 & 0.006 & 0.006\end{array}$

$\begin{array}{lllllllllllllllllllll}0.004 & 0.009 & 0.004 & 0.009 & 0.009 & 0.010 & 0.004 & 0.009 & 0.002 & 0.007 & 0.001 & 0.009 & 0.007 & 0.010 & 0.004 & 0.001 & 0.004 & 0.007\end{array}$

$\begin{array}{llllllllllllllllllllll}0.004 & 0.010 & 0.004 & 0.007 & 0.007 & 0.007 & 0.007 & 0.010 & 0.002 & 0.005 & 0.004 & 0.007 & 0.008 & 0.007 & 0.007 & 0.004 & 0.002 & 0.008 & 0.003 & & & 0.003\end{array}$

$\begin{array}{lllllllllllllllllllllllll}0.010 & 0.002 & 0.010 & 0.002 & 0.005 & 0.003 & 0.009 & 0.002 & 0.009 & 0.005 & 0.007 & 0.002 & 0.001 & 0.003 & 0.005 & 0.006 & 0.007 & 0.004 & 0.007 & 0.007 & & 0.007\end{array}$

$\begin{array}{lllllllllllllllllllllll}0.003 & 0.011 & 0.003 & 0.008 & 0.008 & 0.009 & 0.006 & 0.011 & 0.001 & 0.006 & 0.003 & 0.008 & 0.010 & 0.009 & 0.007 & 0.003 & 0.003 & 0.009 & 0.002 & 0.002 & 0.009\end{array}$

L1-2

\begin{tabular}{llllllllllllllllllllllllll}
0.002 & 0.010 & 0.002 & 0.007 & 0.007 & 0.008 & 0.005 & 0.010 & 0.001 & 0.005 & 0.002 & 0.007 & 0.009 & 0.008 & 0.006 & 0.002 & 0.002 & 0.008 & 0.001 & 0.001 & 0.008 & 0.001 \\
\hline
\end{tabular} 


\section{Discussion}

This research has successfully amplified 16S rRNA gene from fifteen isolates of pathogenic $E$. coli isolated from cow meat. All isolates studied had DNA bands at the appropriate size indicated by the presence of bright thick bands. The DNA fragments of the $E$. coli genome were successfully amplified using primers $27 \mathrm{~F}$ and $1492 \mathrm{R}$ adhered well to specific sites of the DNA template with the optimum temperature during primer annealing (ALatawi et al. 2015). The appearance of a single DNA band indicates that the primer pair used is specific and only attaches to the expected position (Kuczynski et al. 2012; Miyazaki et al. 2017; Sambo et al. 2018). The $16 \mathrm{~S}$ rRNA gene of the fifteen isolates was successfully sequenced from isolates of pathogenic E. coli and aligned with the data available in GenBank. References are from the same and different species or genus. The reference strains are Shiga-toxin producing E. coli (STEC) of E. coli Sakai, E. coli $\mathrm{O} 104: \mathrm{H} 4$, E. coli $\mathrm{EDL} 933 \mathrm{~W}$, E. coli SM-25(1), E. coli KL-48(2), E. coli O111:H-, and E. coli O121:H19, while as an outgroup is $S$. sonnei. Alignment results from the fifteen isolates show that their nucleotide sequence is closely related to isolates from the same species. These results have been supported by $16 \mathrm{~S}$ rRNA gene sequencing as an appropriate method for bacterial identification and agreed with previous studies.

Jenkins et al. (2012) have been successfully used $16 \mathrm{~S}$ rRNA gene sequences to identify bacterial pathogens derived from clinical samples even though specific bacteria are difficult to recognize as they share more than $99 \%$ identity in their 16S rRNA gene sequences. However, sequencing the $16 \mathrm{~S}$ rRNA gene has suggested making an essential contribution to patient management by detecting the pathogenic bacteria in culture-negative clinical samples. Srinivasan et al. (2015) have used the 16S rRNA gene to identify pathogenic bacteria from clinical samples and showed that between $16 \mathrm{~S}$ rRNA gene-based and clinical identities, the concordance rate at the genus level was $96 \%$ and the species level was $87.5 \%$. Meanwhile, Magray et al. (2011) and Tan et al. (2016) have succeeded in characterizing E. coli isolates and found two isolates of pathogenic $E$. coli isolated from drinking water through analysis of $16 \mathrm{~S}$ rRNA gene sequences, respectively. In a previous study, the 16S rRNA gene sequence data have been compared in both conventional and commercial assay formats. Using the $16 \mathrm{~S}$ rRNA gene sequence has shown powerful results of bacterial species identification compared to conventional or commercial methods (Janda and Abbott 2007).

Nucleotide sequence of the fifteen isolates also has some similarities to that of S. sonnei. The reason for this is that $S$. sonnei has the same nucleotide sequence and virulence gene to pathogenic $E$. coli, especially the ones producing Shiga-toxin (Muniesa et al. 2012; NavarroGarcia 2014). According to Bielaszewska et al. (2011), the E. coli $\mathrm{O} 104: \mathrm{H} 4$ that caused the outbreak in Germany has a genome sequence and virulence gene profile of a combination of the STEC strain, namely Shiga-toxin and the enteroaggregative E. coli (EAEC) strain, Shigella enterotoxin Set1. In addition, rRNA sequence-based analysis was used to understand not only microbial diversity within and across groups but also to identify new strains. The fifteen isolates studied had potential as new pathogenic $E$. coli strains and these strains were estimated to have the same characteristics as E. coli Sakai, E. coli O104:H4, E. coli EDL 933 W, E. coli SM-25(1), E. coli KL-48(2), E. coli O111:H-, E. coli O121:H19, and $S$. sonnei.

Grouping and closeness of each isolate in this research and among reference strains are also supported with values of genetic distance and nucleotide differences. Values of genetic distance (Table 1) are in line with the concept of nucleotide similarity and differences put forward by earlier researchers. The genetic distance in this study showed low results, both between the fifteen isolates studied with the reference strain and among each of the fifteen isolates. According to Janda and Abbott (2007), 16S rRNA gene similarity of more than $95 \%$ or nucleotide differences of less than $1 \%$ (15 of $1500 \mathrm{bp}$ ), shows that a nucleotide must be categorized as of the same species. Genetic relationships among populations are depicted using values of genetic distance, with small genetic distance implying close genetic relation (Nei 1972). Similar to what was conveyed by Dharmayanti (2011), the lower the pairwise distance value (genetic distance) means the closer the relationships.

The phylogenetic tree shows that the fifteen isolates may have genetic relationship with reference strains, but it will take more research to prove. Based on the phylogenetic tree, each species found in each traditional market forms a clade that spreads across all clades. A clade is a part of a phylogeny that includes an ancestral lineage and all descendants of that ancestor. This group of organisms has monophyly characteristics, so it is called a monophyletic group. This causes members in monophyletic groups to be considered to have very close relationships and are assumed to carry the same genetic and biochemical traits or patterns (Baum 2008; McLennan 2010). This indicates that the bacteria isolated from each traditional market have close phylogenetic relationships. All fifteen isolates studied had the potential to be the same species although further research was needed. The 0.001 scale refers to the evolutionary distance in branch length. The high nucleotides similarity between $16 \mathrm{~S}$ rRNA genes of isolates that originated from cow meat from the different markets with reference strain showed they have a close relationship with STEC. The same results have also been shown by previous studies from Abuelhassan et al. (2016) who explained in their phylogenetic tree that the studied $E$. coli isolates were in a clade close to and similar to those obtained in other parts of the world. The study showed that all $E$. coli isolates studied were similar to $E$. coli strains isolated in other countries which were pathogenic E. coli. Based on the phylogenetic tree, the closeness of the studied E. coli with E. coli O113:H21 which is a STEC has been reported by Ayoade et al. (2021). Phylogenetic analysis has shown to identify seven clusters among the O26 STEC strain (Norman et al. 2015) and prove the similarity of the pathogenic E. coli isolates studied with $E$. coli isolated from children with diarrhea (Ame'zquita-Montes et al. 2015). High nucleotide similarity between similar $16 \mathrm{~S}$ 
rRNA genes was also found in Suardana (2014). The phylogenetic tree based on nucleotide sequence shows that D2-2 isolate is in one branch with E. coli SM-25(1) with bootstrap value of $79 \%$, both isolates show genetic similarities. Isolate D2-2 is potential of the same characteristics and cytopathic effect with the reference strains as proven by the presence of eae positive gene, and small genetic distance and insignificant nucleotide differences. The discovery of the eae gene in isolate D2-2 raises the potential that this isolate can colonize the host intestine and induce attaching-effacing lesions. E. coli SM25(1) and E. coli KL-48(2) are the same species that have similarities in terms of profile protein (Suardana et al. 2013a), genetic diversity (Suardana et al. 2013b), and the potential to induce lesion in Vero cells (Suardana et al. 2011). E. coli SM-25(1) and E. coli KL-48(2) were isolated from the feces of Balinese cow and a patient of kidney failure, respectively (Suardana et al. 2010). Finding of pathogenic $E$. coli in cow mean indicates the potential for zoonosis. Therefore, a proper treatment regime needs to be chosen in order to avoid antibiotic resistance of such bacteria, especially in this time of COVID-19 pandemic (Wardoyo et al. 2021). Moreover, similarities between isolate $\mathrm{N} 2$ and $S$. sonnei show that isolate N2 could be a strain outside pathogenic $E$. coli that may lead to $S$. sonnei. However, such an assumption requires further confirmation using other genetic markers to better understand the ecology and epidemiology of these two foodborne disease agents (Persad and Lejeune 2018).

In conclusion, the fifteen isolates have small genetic distance to the reference strains, and these fifteen isolates are also in the same clade with reference strains. This research shows that the fifteen isolates under investigation are closely related to the reference strains, which is Shigatoxin producing E. coli (STEC). People should pay more attention in processing food stock, especially cow meat. Further research may focus on determining the strain of those fifteen isolates.

\section{ACKNOWLEDGEMENTS}

The authors gratefully acknowledge the funding of this research provided by The Directorate of Research and Community Service, Directorate General of Research and Development Strengthening, The Ministry of Research, Technology and Higher Education, Republic of Indonesia in the scheme PMDSU research grant 2020 contract no. 3169/UN1.DITLIT/DIT-LIT/PT/2020.

\section{REFERENCES}

Abuelhassan NN, Mutalib SA, Gimba FI, Yusoff WM. 2016. Molecular characterization and phylogeny of Shiga toxin-producing E. coli (STEC) from imported beef meat in Malaysia. Environ Sci Pollut Res 23: 17553-17562. DOI: 10.1007/s11356-016-6954-0

ALatawi A, Sutarno, Susilowati A, Hailu HW. 2015. Biochemical and molecular characterization of food contaminating bacteria isolates from food stall vegetables. Br Microbiol Res J 5 (5): 405-411. DOI: 10.9734/bmrj/2015/13792
Amarantini C, Sembiring L, Kushadiwijaya H, Asmara W. 2011. Identification and characterization of Salmonella typhi isolates from Southwest Sumba District, East Nusa Tenggara based on 16S rRNA gene sequences. Biodiversitas 12 (1): 1-6. DOI: 10.13057/biodiv/d120101

Amézquita-Montes Z, Tamborski M, Kopsombut UG, Zhang C, Arzuza OS, Gómez-Duarte OG. 2015. Genetic relatedness among Escherichia coli pathotypes isolated from food products for human consumption in Cartagena, Colombia. Foodborne Pathog Dis 12 (5): 454-461. DOI: 10.1089/fpd.2014.1881

Antaki-zukoski EM, Li X, Pesavento PA, Nguyen THB, Hoar BR, Atwill ER. 2018. Comparative pathogenicity of wildlife and bovine Escherichia coli O157: H7 strains in experimentally inoculated neonatal jersey calves. Vet Sci 5 (88): 1-11. DOI: 10.3390/vetsci5040088

Ayoade F, Oguzie J, Eromon P, Omotosho OE, Ogunbiyi T, Olumade T, Akano K, Folarin O, Happi C. 2021. Molecular surveillance of shiga toxigenic Escherichia coli in selected beef abattoirs in Osun State Nigeria. Nature portofolio 11: 13966. DOI: 10.1038/s41598-02193347-w

Baum D. 2008. Reading a phylogenetic tree: The meaning of monophyletic.

Bielaszewska M, Mellmann A, Zhang W, Köck R, Fruth A, Bauwens A, Peters G, Karch H. 2011. Characterisation of the Escherichia coli strain associated with an outbreak of haemolytic uraemic syndrome in Germany, 2011: A microbiological study. Lancet Infect Dis 11 (9): 671-676. DOI: 10.1016/S1473-3099(11)70165-7

Blanco M, Blanco JE, Mora A, Dahbi G, Alonso MP, González EA, Bernárdez MI, Blanco, J. 2004. Serotypes, virulence genes, and intimin types of Shiga toxin (verotoxin)-producing Escherichia coli isolates from healthy sheep in Spain and identification of a new intimin variant gene $(e a e-\xi)$. J Clin Microbiol 42 (2): 645-651. DOI: 10.1128/JCM.42.2.645-651.2004

Botkin DJ, Galli L, Sankarapani V, Soler M, Rivas M, Torres AG. 2012. Development of a multiplex PCR assay for detection of Shiga toxinproducing Escherichia coli, enterohemorrhagic E. coli, and enteropathogenic E. coli strains. Front Cell Infect Microbiol 2 (8): 1 10. DOI: $10.3389 /$ fcimb.2012.00008

CDC. 2014. Questions and answers E. coli. https://www.cdc.gov/ecoli/general/index.html

CFSPH. 2016. Enterohemorrhagic Escherichia coli and other E. coli causing hemolytic uremic syndrome Center for Food Security and Public Health Technical Factsheets 61. Iowa State University Center for Food Security and Public Health. https://lib.dr.iastate.edu/cfsph_factsheets/61

Croxen MA, Finlay BB. 2010. Molecular mechanisms of Escherichia coli pathogenicity. Nat Rev Microbiol 8: 26-38. DOI: $10.1038 /$ nrmicro2265

Dharmayanti NLPI. 2011. Molecular phylogenetic: organism taxonomy method based on evolution history. Wartazoa 21 (1): 1-10. [Indonesian]

Donnenberg MS, Tzipori S, McKee ML, O’Brien AD, Alroy J, Kaper JB. 1993. The role of the eae gene of enterohemorrhagic Escherichia coli in intimate attachment in vitro and in a porcine model. J Clin Invest 92 (3): 1418-1424. DOI: 10.1172/JCI116718

Fialho OB, de Souza EM, de Borba Dallagassa C, de Oliveira Pedrosa F, Klassen G, Irino K, Paludo KS, de Assis FEA, Surek M, Farah SMDS, Fadel-Picheth CMT. 2013. Detection of diarrheagenic Escherichia coli using a two-system multiplex-PCR protocol. J Clin Lab Anal 27: 155-161. DOI: 10.1002/jcla.21578

Fujioka M, Kasai K, Miura T, Sato T, Otomo Y. 2009. Rapid diagnostic method for the detection of diarrheagenic Escherichia coli by multiplex PCR. Jpn J Infect Dis 62: 476-480.

Ghazali NSH, Rashid NHA. 2019. Molecular identification of bacterial communities from vegetables samples as revealed by DNA sequencing of universal primer 16S rRNA gene. Int J Med Sci 4 (1): 19-26.

Gomes TAT, Elias WP, Scaletsky ICA, Guth BEC, Rodrigues JF, Piazza RMF, Ferreira LCS, Martinez MB. 2016. Diarrheagenic Escherichia coli. Braz J Microbiol 47: 3-30. DOI: 10.1016/j.bjm.2016.10.015

Habets A, Engelen F, Duprez J, Devleesschauwer B, Heyndrickx M, Zutter LD, Thiry D, Cox E, Mainil J. 2020. Identification of Shigatoxigenic and enteropathogenic Escherichia coli serotypes in healthy young dairy calves in Belgium by recto-anal mucosal swabbing. Vet Sci 7 (167): 1-10. DOI: 10.3390/vetsci7040167 
Indraswari A, Haryanto A, Suardana IW, Widiasih DA. 2021. Isolation and detection of four major virulence genes in O157:H7 and nonO157 E. coli from beef at Yogyakarta Special Province, Indonesia. J Anim Heal Prod.

Jafari A, Aslani MM, Bouzari S. 2012. Escherichia coli: a brief review of diarrheagenic pathotypes and their role in diarrheal diseases in Iran. Iran J Microbiol 4 (3): 102-117.

Janda JM, Abbott SL. 2007. 16S rRNA gene sequencing for bacterial identification in the diagnostic laboratory: pluses, perils, and pitfalls. J Clin Microbiol 45 (9): 2761-2764. DOI: 10.1128/JCM.01228-07

Jenkins C, Ling CL, Ciesielczuk HL, Lockwood J, Hopkins S, McHugh TD, Gillespie SH, Kibbler CC. 2012. Detection and identification of bacteria in clinical samples by $16 \mathrm{~S}$ rRNA gene sequencing: comparison of two different approaches in clinical practice. J Med Microbiol 61: 483-488. DOI: 10.1099/jmm.0.030387-0

Kuczynski J, Lauber CL, Walters WA, Parfrey LW, Clemente JC, Gevers D, Knight R. 2012. Experimental and analytical tools for studying the human microbiome. Nat Rev Genet 13 (1): 47-58. DOI: $10.1038 / \operatorname{nrg} 3129$

Kumar S, Stecher G, Li M, Knyaz C, Tamura K. 2018. MEGA X molecular evolutionary genetics analysis across computing platforms. Mol Biol Evol 35 (6): 1547-1549. DOI: 10.1093/molbev/msy096

Magray MSUD, Kumar A, Rawat AK, Srivastava S. 2011. Identification of Escherichia coli through analysis of 16S rRNA and 16S-23S rRNA internal transcribed spacer region sequences. Bioinformation 6 (10): 370-371. DOI: 10.6026/97320630006370

McLennan DA. 2010. How to read a phylogenetic tree. Evol Educ Outreach 3: 506-519. DOI: 10.1007/s12052-010-0273-6

Miyazaki K, Sato M, Tsukuda M. 2017. PCR primer design for 16 S rRNAs for experimental horizontal gene transfer test in Escherichia coli. Front Bioeng Biotechnol 5 (14): 1-7. DOI: 10.3389/fbioe.2017.00014

Muniesa M, Hammerl JA, Hertwig S, Appel B, Brüssow H. 2012. Shiga toxin-producing Escherichia coli O104:H4: a new challenge for microbiology. Appl Environ Microbiol 78 (12): 4065-4073. DOI: 10.1128/AEM.00217-12

Nataro JP, Kaper JB. 1998. Diarrheagenic Escherichia coli. Clin Microbiol Rev 11 (2): 403-403. DOI: 10.1128/CMR.11.2.403

Navarro-Garcia F. 2014. Escherichia coli O104:H4 pathogenesis: an enteroaggregative $E$. coli /Shiga toxin-producing $E$. coli explosive cocktail of high virulence. Microbiol Spectr 2 (6): 1-19. DOI 0.1128/microbiolspec.ehec-0008-2013

Nei M. 1972. Genetic distance between populations. Am Nat 106 (949): 283-92.

Ningrum SG, Soejoedono RD, Latif H, Arnafia W, Wibawan IWT. 2016. Prevalence and characterization of shiga toxin-producing Escherichia coli isolated from slaughtered qurban animal in Jakarta Province. Media Peternakan 39 (2): 90-94. DOI: 10.5398/medpet.2016.39.2.90 [Indonesian]

Norman KN, Clawson ML, Strockbine NA, Mandrell RE, Johnson R, Ziebell K, Zhao S, Fratamico PM, Stones R, Allard MW, Bono JL. 2015. Comparison of whole genome sequences from human and non human Escherichia coli O26 strains. Front Cell Infect Microbiol 5: 110. DOI: $10.3389 /$ fcimb.2015.00021

Oswald E, Schmidt H, Morabito S, Karch H, Marchès O, Caprioli A 2000. Typing of intimin genes in human and animal enterohemorrhagic and enteropathogenic Escherichia coli: characterization of a new intimin variant. Infect Immun 68 (1): 64-71. DOI: 10.1128/IAI.68.1.64-71.2000

Pangastuti A. 2006. Species definition of procaryotes based on 16S rRNA and protein coding genes sequence. Biodiversitas 7 (3): 292-296. DOI: 10.13057/biodiv/d070319. [Indonesian]

Patel J. 2001. 16S rRNA gene sequencing for bacterial pathogen identification in the clinical laboratory. Mol Diagn 6 (4): 313-21. DOI: $10.1054 /$ modi.2001.29158

Persad AK, Lejeune J. 2018. A review of current research and knowledge gaps in the epidemiology of Shiga toxin-producing Escherichia coli and Salmonella spp. in Trinidad and Tobago. Vet Sci 5 (42): 1-9. DOI: $10.3390 /$ vetsci5020042

Rahmani S, Mosavp M, Rezaeej A. 2006. Detection of bacteria by amplifying the 16S rRNA gene with universal primers and RFLP. Med J Islam Repub Iran 19 (4): 333-338.

Rananda RM, Djamal A, Julizar. 2016. Identification of Escherichia coli O157:H7 bacteria in beef from Lubuk Buaya slaughterhouse. J Kesehatan Andalas 5 (3): 614-618. DOI: 10.25077/jka.v5i3.586. [Indonesian]

Rinanda T. 2011. Analysis of 16S rRNA sequences in the field of microbiology. J Kedokt Syiah Kuala 3: 172-177. [Indonesian]

Saitou N, Nei M. 1987. The neighbor-joining method: a new method for reconstructing phylogenetic trees. Mol Biol Evol 4 (4): 406-425. DOI: 10.1093/oxfordjournals.molbev.a040454

Sambo F, Finotello F, Lavezzo E, Baruzzo G, Masi G, Peta E, Falda M, Toppo S, Barzon L, Di Camillo B. 2018. Optimizing PCR primers targeting the bacterial $16 \mathrm{~S}$ ribosomal RNA gene. BMC Bioinformatics 19 (343): 1-10. DOI: 10.1186/s12859-018-2360-6

Srinivasan R, Karaoz U, Volegova M, MacKichan J, Kato-Maeda M, Miller S, Nadarajan R, Brodie EL, Lynch SV. 2015. Use of 16S rRNA gene for identification of a broad range of clinically relevant bacterial pathogens. PLoS One 10 (2): e0117617. DOI: 10.1371/journal.pone.0117617

Suardana IW, Sumiarto B, Lukman DW. 2007. Isolation and identification Escherichia coli 0157:H7 on beef at Badung Regency Province of Bali. J Vet 8 (1): 16-23. [Indonesian]

Suardana IW, Artama WT, Asmara W, Daryono BS. 2010. Identification of Escherichia coli O157:H7 and detection of Shiga like toxin 1 and 2 genes from animal feces beef, and human feces. J Vet 1 (4): 264-270. [Indonesian]

Suardana IW, Artama WT, Asmara W, Daryono BS. 2011. Adherence pheno-genotypic of Escherichia coli O157:H7 isolated from beef, feces of cattle, chicken and human. Indones J Biotechnol 16 (1): 4652. DOI: $10.22146 /$ ijbiotech. 15990

Suardana IW, Pinatih KJP, Ratnawati NLKA, Widiasih DA. 2013a. Protein profile analysis of Escherichia coli O157:H7 from human and animals origin. Int J Curr Microbiol Appl Sci 2 (6): 204-214.

Suardana IW, Artama WT, Widiasih DA, Ngurah IG, Mahardika K. 2013b. Genetic diversity of Escherichia coli O157:H7 strains using random amplified polymorphic DNA (RAPD). Int Res J Microbiol 4 (2): 72-78.

Suardana IW, Widiasih DA, Nugroho WS, Wibowo MH, Suyasa IN. 2017. Frequency and risk-factors analysis of Escherichia coli O157:H7 in Bali-cattle. Acta Trop 172: 223-228. DOI: 10.1016/j.actatropica.2017.05.019

Suardana IW. 2014. Analysis of nucleotide sequences of the 16S rRNA gene of novel Escherichia coli strains isolated from feces of human and Bali cattle. J Nucleic Acids 2014: 1-7. DOI: $10.1155 / 2014 / 475754$

Tan EY, Arifullah M, Soon JM. 2016. Identification of Escherichia coli strains from water vending machines of Kelantan, Malaysia using 16S rRNA gene sequence analysis. Expo Heal 8: 211-216. DOI: 10.1007/s12403-016-0194-x

Vidal A, Aguirre L, Seminati C, Tello M, Redondo N, Martin M, Darwich L. 2020. Antimicrobial resistance profiles and characterization of Escherichia coli strains from cases of neonatal diarrhea in Spanish Pig Farms. Vet Sci 7 (48): 1-12. DOI: 10.3390/vetsci7020048

Wardoyo EH, Suardana IW, Yasa IWPS, Sukrama IDM. 2021. Antibiotics susceptibility of Escherichia coli isolates from clinical specimens before and during COVID-19 pandemic. Iran J Microbiol 13 (2): 156160. DOI: $10.18502 / \mathrm{ijm} . v 13 \mathrm{i} 2.5974$

WHO. 2018. Key facts p. 1-7. https://www.who.int/news-room/factsheets/detail/e-coli

Yousif AA, Hussein MA. 2015. Prevalence and molecular detection of intimin (eaeA) virulence gene in E. coli $\mathrm{O} 157: \mathrm{H} 7$ in calves. Res J Vet Pract 3 (3): 47-52. DOI: 10.14737/journal.rjvp/2015/3.3.47.52 